\title{
Preparation of Cassava Bagasse Starch-Based Biodegradable Film Reinforced with Chicken Feet Gelatin, Citric Acid as Crosslinker, and Glycerol as Plasticizer
}

\author{
Silviana Silviana*, Piontek Benedictus Brandon, and Bella Ayu Silawanda \\ Department of Chemical Engineering, Faculty of Engineering, Diponegoro University, \\ Jl. Prof. Sudarto, SH, Kampus Tembalang, Semarang 50268, Indonesia
}

Received July 19, 2017; Accepted January 1, 2018

\begin{abstract}
Chicken feet is one of sources used to produce biodegradable films due to inexpensive and abundant source. Chicken feet contains extracted gelatin amount of 27.61 to 33\%. This biofilm was prepared from cassava bagasse starch with citric acid as cross-linker and glycerol as plasticizer. Cassava bagasse contains about 40-64\% of starch. This paper observes the optimum composition of cassava bagasse starch-based biofilm preparation upon Central Composite Design using three variables of gelatin, glycerol, and citric acid concentrations with response of tensile strength and elongation at break. This research was executed in several steps, i.e. extraction of gelatin, extraction of cassava bagasse starch, and casting. Optimum condition of this biofilm preparation can be obtained at 12.98 wt. $\%$ of gelatin content, $0.22 \mathrm{wt} . \%$ of glycerol and $0.27 \mathrm{wt} . \%$ of citric acid by releasing $21.73 \mathrm{MPa}$ of tensile strength and $19.73 \%$ of elongation at break. Mass loss of biofilm with lower gelatin content gave almost the same mass loss for blank biofilm (cassava bagasse starch-based without gelatin content). Increasing of gelatin content in the biofilm, increasing of the biofilm mass loss. However, the biofilm had good thermal stability by thermal gravimetric analysis with higher temperature to obtain inorganic residue than that of blank biofilm.
\end{abstract}

Keywords: biofilm; cassava bagasse starch; chicken feet; gelatin

\section{ABSTRAK}

Kaki ayam merupakan salah satu sumber dari bahan biofilm biodegradable terkait harga murah dan ketersediaan melimpah. Kaki ayam mengandung gelatin sebesar 27,61 hingga 33\%. Biofilm ini dibuat dari pati dari onggok singkong dengan asam sitrat sebagai cross-linker, dan gliserol sebagai plasticizer. Onggok singkong mengandung 40-60\% pati. Makalah ini mengkaji komposisi optimum dari biofilm berbahan onggok singkong berdasarkan central composite design menggunakan tiga variabel konsentrasi gelatin, gliserol dan asam sitrat. Kajian penelitian ini melewati beberapa tahap, yaitu ekstraksi gelatin, ekstraksi pati dari onggok singkong, dan pencetakan. Kondisi optimum dapat dicapai pada komposisi 12,98\% berat gelatin, 0,22\% berat gliserol, dan 0,27\% asam sitrat dengan menghasilkan kekuatan tarik sebesar 21,73 MPa dan elongation at break sebesar 19,73\%. Hilang massa dari biofilm dengan kandungan gelatin rendah menunjukkan hal sama dengan hilang massa dari biofilm blank (biofilm berbahan pati onggok singkong tanpa gelatin). Kenaikan gelatin menyebabkan kenaikan hilang massa biofilm. Namun demikian, biofilm memberikan ketahanan terhadap panas berdasarkan analisa termal gravimetri dengan temperatur tinggi untuk mendapatkan sisa anorganiknya.

Kata Kunci: biofilm; gelatin; kaki ayam; pati onggok singkong

\section{INTRODUCTION}

Biodegradable film is one of the solutions to overcome problem of non-degradable plastic usage. Research on the production of biodegradable films has been widely practiced. Based on previous research, biodegradable films can be made from the bacteria Pseudomonas oleovorans [1], chicken feathers [2], soy protein [3], bacterial of polysaccharide FucoPol [4], chicken breast protein [5], protein from sunflower [6], cassava starch [7], spinach flour [8], rice flour mixture with

* Corresponding author

Email address : silviana@che.undip.ac.id polybutylene adipate co-terephtalate [9], a mixture of corn starch and chitosan [10].

Some studies of chicken feet-based biodegradable films have been observed including using leather-based brown gelatin material with the addition of glycerol, sorbitol and polyethylene glycol [11], soy protein isolate [12], and montmorillonite as filler [13]. Glycerol is chosen to be a plasticizer because it is most effective in flexibility to protein-based films (gelatin) [14]. In addition of glycerol is very affordable price [15]. Meanwhile, citric acid can increase the level of elongation and reduce the water content of the biofilm [16]. Glycerol, starch, and DOI: 10.22146/ijc.26766

Silviana et al. 
citric acid are a very suitable combination in preparation of good biofilms [16]. Use of chicken feet gelatin with plasticizers can reduce chain-to-chain interaction and release flexibility, moisture resistance and easy in preparation [17].

In this paper, cassava bagasse starch based biodegradable film was prepared with the addition of chicken feet gelatin, citric acid as crosslinker and glycerol as plasticizer by using response surface methodology to optimize the condition for the biodegradable film preparation. The design of experiment was executed applying Design Expert 8.0.6 (Stat-Ease Inc., USA). Central Composite Design (CCD) employed three variables of gelatin, citric acid, and glycerol concentrations. The effects of these variables on the mechanical properties (tensile strength and elongation at break) were observed on surface plots and contour plots. Furthermore, at the optimum condition of biofilm was compared to blank sample (without gelatin) in several analyses such as durability test, structural by FTIR, thermal stability by thermogravimetry analysis to confirm the results.

\section{EXPERIMENTAL SECTION}

\section{Materials}

Chicken feet were obtained from chicken supplier in Kedungmundu-Semarang. Cassava bagasse was delivered from small entrepreneur in Pati. Citric acid was supplied from Sigma Aldrich (99\%). Glycerol (50\%) and $\mathrm{H}_{3} \mathrm{PO}_{4}(99 \%)$ were supplied from PT. Brataco Semarang. $\mathrm{HCl}$ with $37 \%$ was produced from Mallinckrodt, $\mathrm{KCl}$ (pro analysis, 99\%) and $\mathrm{NaOH}$ (pro analysis, 99\%) were supplied by Merck.

\section{Instrumentation}

Response data in this research were obtained from analysis of tensile strength and elongation at break by using Texture Analyzer plus (LLOYD Instrument), analysis of central composite design (Design Expert 8.0.6, Stat-Ease, Inc.), FTIR analysis by IRTracer-100 (Shimadzu) and DRS-8000 (Shimadzu), TGA analysis by TGA Analyzer DTG-60, ultrasonic homogenizer (FS$250 \mathrm{~N})$.

\section{Procedure}

\section{Preliminary}

In the beginning, commercial starch and cassava bagasse starch were analyzed amylose content by proximate analysis. The experimental design was created by using Design Expert 8.0.6 with variables level in Table 1. This design of experiments wrapped 20 runs including
Table 1. Coded levels of variables in CCD

\begin{tabular}{llllrr}
\hline Variables & \multicolumn{5}{c}{ Coded level wt.\%) } \\
\cline { 2 - 6 } & \multicolumn{1}{c}{$\alpha$} & -1 & 0 & \multicolumn{1}{c}{1} & $\alpha$ \\
\hline A: Gelatin & 1.23 & 6.0 & 13.0 & 20.0 & 24.77 \\
B: Glycerol & 0.03 & 0.1 & 0.2 & 0.3 & 0.37 \\
C: Citric acid & 0.005 & 0.08 & 0.19 & 0.3 & 0.37 \\
\hline$\alpha=1.6818$ & \multicolumn{6}{c}{}
\end{tabular}

$$
\alpha=1.6818
$$

six axial experiments (levels $\pm \alpha$ ), eight factorial experiments (levels \pm 1 ), and six replicates in the center point. The research was executed at Advance Material Laboratory (AMaL) Department of Chemical Engineering, Diponegoro University. The research divided into four stages, i.e. chicken gelatin extraction, cassava bagasse starch extraction, preparation of polymer solution and casting process, then results analysis.

\section{Experiments}

The gelatin extraction method used referred to previous research with slight modifications [18]. This slight modification was referred using without freeze storage prior to use. Chicken feet was skinned and dried using sunlight and then it was sized by using a crusher. Then, chicken feet were soaked in water with temperature of $35^{\circ} \mathrm{C}$ with constant stirring to remove fat and then washed using running water. After that, the chicken feet were demineralized by soaking in $3 \%$ of $\mathrm{HCl}$ solution for $24 \mathrm{~h}$ at $10{ }^{\circ} \mathrm{C}$ then washed with water to remove acid excess to attain $\mathrm{pH}$ above 4 . Next, the chicken feed was soaked in $\mathrm{NaOH}$ solution $(4 \mathrm{~g} / 100 \mathrm{~mL}$ ) for $72 \mathrm{~h}$ at room temperature. Then the chicken feed was washed with water to remove the excess base. Furthermore, the extraction process was done by soaking chicken feet in aquadest with $\mathrm{pH}$ of 4 (adjusted by using $\mathrm{H}_{3} \mathrm{PO}_{4}$ ) with constant stirring. After extraction, the material was centrifuged for $30 \mathrm{~min}$ then the supernatant was filtered using Whatman filter paper. The filtrate result was concentrated using rotary evaporation. Finally, it was freeze dried prior to make powder. Preparation of cassava bagasse was executed by washing and sizing. The bagasse was dissolved in water and filtered a filter cloth. Filtrate was collected and then left a few days. The water at the top of the precipitate was removed, while the precipitate was collected. The sun dried precipitated slurry. After drying, the starch was then sieved to obtain the cassava bagasse starch with fine powder.

The preparation of a polymer solution refers to the previous method with slight modifications [19]. Gelatin and glycerol were added according to the variables as well as $1.6 \mathrm{~g}$ of cassava bagasse starch added to beaker glass then dissolved in $40 \mathrm{~mL}$ aquadest and then homogenized with ultrasonic processor FS-250N for $1 \mathrm{~h}$. After that the solution was heated and maintained to 
$90{ }^{\circ} \mathrm{C}$ for $15 \mathrm{~min}$ with constant stirring, then the temperature was lowered to $65^{\circ} \mathrm{C}$ and fed the citric acid according to the variable and then stirred using constant stirring for $15 \mathrm{~min}$. The changed variables used in this study were gelatin concentrations $(1.23,6,13,20$, and 24.77 wt.\%), glycerol concentrations $(0.03,0.1,0.2,0.3$, and 0.37 wt.\%) and citric acid concentrations (0.01, 0.08, $0.19,0.3$, and 0.37 wt.\%).

Biodegradable film was assessed the mechanical properties at the Soegijapranata Food Tech Laboratory Semarang using TA Plus Texture Analyzer. The tensile strength (TS) and elongation at break $(\varepsilon)$ as response data referred to the method described by Firdaus [20]. FTIR analysis by IRTracer-100 (Shimadzu) and DRS8000 (Shimadzu) at Muhammadiyah University of Purwokerto, and TGA analysis was conducted at Laboratorium Penelitian dan Pengujian Terpadu of Universitas Gajah Mada.

Degradation rate denotes to the biodegradability of film in certain relative humidity condition. The film product was cut into $2.8 \mathrm{~cm} \times 1.6 \mathrm{~cm}$ and weighed the initial mass and measured its initial moisture content. Furthermore, the film was buried in soil replacing into the desiccator. The conditions in the desiccator were set in relative humidity of $85 \%$ using $\mathrm{KCl}$ solution. Afterward, mass loss and moisture content were observed in every $24 \mathrm{~h}$ for 45 days.

\section{RESULT AND DISCUSSION}

\section{Preliminary Result}

Based on a proximate analysis, it can be concluded that cassava bagasse starch was potential source due to high content of starch (as amylose). Commercial starch denoted higher of amylose content than that of cassava bagasse starch. It was obtained $16.7 \%$ of amylose for commercial starch and $12.1 \%$ of amylose for cassava bagasse starch. It was denoted that cassava bagasse starch has a potential material for biofilm preparation. At the beginning, it was observed run of each variable by preliminary research. Then, the range of variables were used in CCD to obtain optimum of tensile strength as mechanical property. The results of mechanical analysis of biofilm trial products are presented in Table 2.

Table 2. Preliminary research of tensile strength

\begin{tabular}{ccccc}
\hline No & $\begin{array}{c}\text { Gelatin } \\
\text { (wt.\%) }\end{array}$ & $\begin{array}{c}\text { Glycerol } \\
\text { (wt.\%) }\end{array}$ & $\begin{array}{c}\text { Citric acid } \\
\text { (wt.\%) }\end{array}$ & $\begin{array}{c}\text { Tensile strength } \\
\text { (MPa) }\end{array}$ \\
\hline 1 & 20 & 0.77 & 0.5 & 1.73 \\
2 & 20 & 0.24 & 0.5 & 2.12 \\
3 & 0 & 0.24 & 0.12 & 10.35 \\
4 & 20 & 0.24 & 0.12 & 12.27 \\
\hline
\end{tabular}

Table 3. The responses of mechanical properties for the CCD of the biofilm

\begin{tabular}{ccccccccc}
\hline No & \multicolumn{3}{c}{ Coded } & \multicolumn{3}{c}{ Actual } & \multicolumn{2}{c}{ Responses } \\
\cline { 2 - 8 } & A & B & C & $\begin{array}{c}\text { Gelatin } \\
\text { (wt.\%) }\end{array}$ & $\begin{array}{c}\text { Glycerol } \\
\text { (wt.\%) }\end{array}$ & $\begin{array}{c}\text { Citric acid } \\
\text { (wt. \%) }\end{array}$ & $\begin{array}{c}\text { Tensile } \\
\text { strength (MPa) }\end{array}$ & $\begin{array}{c}\text { Elongation } \\
\text { at break (\%) }\end{array}$ \\
\hline 1 & -1 & -1 & -1 & 6 & 0.1 & 0.08 & - & - \\
2 & -1 & -1 & +1 & 6 & 0.1 & 0.3 & 20.54 & 8.62 \\
3 & -1 & +1 & -1 & 6 & 0.3 & 0.08 & 1.81 & 4.1 \\
4 & -1 & +1 & +1 & 6 & 0.3 & 0.3 & 16.56 & 6.28 \\
5 & +1 & -1 & -1 & 20 & 0.1 & 0.08 & 0.17 & 0.04 \\
6 & +1 & -1 & +1 & 20 & 0.1 & 0.3 & 13.59 & 7.08 \\
7 & +1 & +1 & -1 & 20 & 0.3 & 0.08 & 6.65 & 2.92 \\
8 & +1 & +1 & +1 & 20 & 0.3 & 0.3 & 8.08 & 13.96 \\
9 & $-\alpha$ & 0 & 0 & 1.23 & 0.2 & 0.19 & 17.9 & 4.98 \\
10 & $+\alpha$ & 0 & 0 & 24.77 & 0.2 & 0.19 & 16.47 & 7.58 \\
11 & 0 & $-\alpha$ & 0 & 13 & 0.03 & 0.19 & - & - \\
12 & 0 & $+\alpha$ & 0 & 13 & 0.37 & 0.19 & 14.47 & 6.54 \\
13 & 0 & 0 & $-\alpha$ & 13 & 0.2 & 0.005 & 2.8 & 4.96 \\
14 & 0 & 0 & $+\alpha$ & 13 & 0.2 & 0.37 & 12.8 & 7.7 \\
15 & 0 & 0 & 0 & 13 & 0.2 & 0.19 & 14.42 & 18.66 \\
16 & 0 & 0 & 0 & 13 & 0.2 & 0.19 & 23.19 & 26.07 \\
17 & 0 & 0 & 0 & 13 & 0.2 & 0.19 & 18.23 & 9.56 \\
18 & 0 & 0 & 0 & 13 & 0.2 & 0.19 & 14.3 & 10.29 \\
19 & 0 & 0 & 0 & 13 & 0.2 & 0.19 & 18.98 & 10.51 \\
20 & 0 & 0 & 0 & 13 & 0.2 & 0.19 & 20.46 & 10.42 \\
\hline
\end{tabular}


Table 4. ANOVA for regression of coeffcient in the tensile strength of biofilm

\begin{tabular}{lccccc}
\hline Source & Sum of squares & df & Mean square & F value & Prob $>F$ \\
\hline Model & 31.42 & 9 & 3.49 & 7.29 & 0.0023 significant \\
A-Gelatin & 0.084 & 1 & 0.084 & 0.17 & 0.6851 \\
B-Glycerol & 3.13 & 1 & 3.13 & 6.54 & 0.0285 \\
C-Citric Acid & 11.65 & 1 & 11.65 & 24.31 & 0.0006 \\
AB & 0.057 & 1 & 0.057 & 0.12 & 0.7376 \\
AC & 1.34 & 1 & 1.34 & 2.79 & 0.1255 \\
BC & 1.87 & 1 & 1.87 & 3.90 & 0.0764 \\
$A^{2}$ & 0.19 & 1 & 0.19 & 0.39 & 0.5443 \\
$B^{2}$ & 0.19 & 1 & 8.81 & 18.39 & 0.0016 \\
C $^{2}$ & 0.19 & 1 & 5.76 & 12.01 & 0.0061 \\
Lack of fit & 3.99 & 5 & 0.8 & 4.96 & 0.0517 \\
\hline
\end{tabular}

Table 5. ANOVA for regression of coeffcient in the elongation at break of biofilm

\begin{tabular}{lclcrl}
\hline Source & Sum of squares & $\mathrm{df}$ & Mean square & F value & Prob $>\mathrm{F}$ \\
\hline Model & 14.77 & 9 & 1.64 & 6.38 & 0.0039 significant \\
A-Gelatin & 0.065 & 1 & 0.065 & 0.25 & 0.6257 \\
B-Glycerol & 3.59 & 1 & 3.59 & 13.98 & 0.0039 \\
C-Citric Acid & 3.45 & 1 & 3.45 & 13.40 & 0.0044 \\
$\mathrm{AB}$ & 0.043 & 1 & 0.043 & 0.17 & 0.6917 \\
$\mathrm{AC}$ & 0.075 & 1 & 0.075 & 0.29 & 0.6016 \\
$\mathrm{BC}$ & 0.96 & 1 & 0.96 & 3.73 & 0.0822 \\
$\mathrm{~A}^{2}$ & 1.00 & 1 & 1.00 & 3.90 & 0.0766 \\
$\mathrm{~B}^{2}$ & 5.51 & 1 & 5.51 & 21.43 & 0.0009 \\
$\mathrm{C}^{2}$ & 0.99 & 1 & 0.99 & 3.83 & 0.0787 \\
Lack of fit & 1.81 & 5 & 0.36 & 2.37 & 0.1824 \\
\hline
\end{tabular}

\section{Mechanical Analysis}

The research used statistical methods (Central Composite Design) to determine the significant variables regard with the mechanical performance of biofilms produced. Response surface method was previously employed to optimize preparation of biocomposites based on poly(lactic acid) and durian peel cellulose [21], preparation of carboxymethyl cellulose [22], and preparation of amaranth flour plasticized with glycerol and sorbitol [8]. Concentration of gelatin (A), glycerol (B) and citric acid (C) acted as independent variables, while the responses were tensile strength $(\mathrm{T})$ and elongation at break $(\varepsilon)$. The experimental design with CCD and the mechanical analysis result were presented in Table 3 . Analysis of variance (ANOVA) results for tensile strength ( $T$ ) responses were shown in Table 4. All the responses was analyzed by using ANOVA and regression analysis for model fitting to evaluate the significance of the coefficient terms. Final equation of model in terms of coded factors of tensile strength response generated as follows in equation (1). This equation model fit was suitable with $R^{2}$ value of 0.8677 . This value indicated $13.23 \%$ of tensile strength variation.

$\sqrt{(T+0.6)}=4.34-0.08 \mathrm{~A}+0.92 \mathrm{C}+0.08 \mathrm{AB}-0.41 \mathrm{AC}-$ $0.48 B C-0.11 A^{2}-0.78 B^{2}-0.63 C^{2}$

where $T$ is the tensile strength, and $A, B, C$ denoted as variable of gelatin $(A)$, glycerol $(B)$ and citric acid $(C)$ with codes values. Furthermore, final equation of model in terms of actual factors of tensile strength response can be declared in equation (2) with the $R^{2}$ value of 0.8677 .

Further meaning, the model equation had 0.8517 denoting the variation of elongation at break of $14.83 \%$.

$\sqrt{(T+0.6)}=-6.15+\left(0.13^{*}\right.$ Gelatin $)+\left(42.86^{*}\right.$

Glycerol $)+(43.94$ * Citric acid $)+(0.12$ * Gelatin *

Glycerol $)-\left(0.53^{*}\right.$ Gelatin ${ }^{*}$ Citric acid $)-\left(43.95^{*}\right.$

Glycerol * Citric acid $)-\left(2.34{ }^{*}\right.$ Gelatin $\left.^{2}\right)-(78.2$ *

Glycerol $\left.{ }^{2}\right)-\left(52.23 *{ }^{*}\right.$ Citric acid $\left.^{2}\right)$

The regression model of tensile strength was $0.0023(p<0.05)$ which also indicated that the model was significant. However, the gelatin $(A)$ variable has no significant effect on the response of tensile strength with higher probability than $0.05(0.6851)$. This condition also was same occurred for the response of elongation at break. Final equation of model in terms of coded factors $\left(R^{2}=0.8677\right)$ of elongation at break response generated equation (3). This model of elongation at break fit significantly at $0.0039(p<0.05)$. The gelatin $(A)$ variable also has no significant effect on the response of elongation at break with higher probability than 0.05 (0.6257). While, glycerol (B) and citric acid (C) have a significant effect due to $p$ value $<0.05$ and $F>1$. Therefore, positive coefficients for both regression model equations indicated a favorable effect for glycerol and citric acid concentrations with higher coefficient than the coefficient of gelatin in the both model equations. 
$\operatorname{Ln}(\varepsilon+0.9)=2.65+0.07 \mathrm{~A}++0.51 \mathrm{~B}+0.5 \mathrm{C}+0.07 \mathrm{AB}+$ $0.1 A C-0.35 B C-0.26 A^{2}-0.62 B^{2}-0.26 C^{2}$

Where $\varepsilon$ is the elongation at break, and $A, B, C$ denoted as variables of gelatin $(A)$, glycerol $(B)$ and citric acid $(C)$ with codes values. Final equation of model in terms of actual factors of elongation at break response can be declared in equation (4)

$\operatorname{Ln}(\varepsilon+0.9)=-4.15+\left(0.1^{*}\right.$ Gelatin $)+\left(34.5^{*}\right.$ Glycerol $)+$

$\left(17.45^{*}\right.$ Citric acid $)+\left(0.1^{*}\right.$ Gelatin * Glycerol $)-$

$\left(0.13^{*}\right.$ Gelatin * Citric acid $)-(31.5 *$ Glycerol *

Citric acid $)-\left(5.38 *\right.$ Gelatin $\left.^{2}\right)-(61.84$ *

Glycerol $\left.^{2}\right)-\left(21.62 *\right.$ Citric acid $\left.^{2}\right)$

According to Lee (2015), plasticizers that would be appropriate with the gelatin and produce good tensile strength were sorbitol compared to glycerol and more preferably when combined combinations of sorbitol and glycerol plasticizers with a ratio of $2: 1$ [19]. According to Mekonnen [17], suitable plasticizers for gelatin-based films are oleic acid, sorbitol, and mannitol. Many of the hydroxyl groups $(-\mathrm{OH})$ in the plasticizer molecule structure determine the number of bonds that can be formed in biofilms [23]. These kinds of plasticizer can be seen in Fig. 1. It appears that the structure of the glycerol molecule has a much less hydroxyl group $(-\mathrm{OH})$ than sorbitol and mannitol, causing glycerol to can release much less polymeric interconnections than sorbitol and mannitol. In this case glycerol is only capable of forming bonds with starch and citric acid so that bonding with gelatin is reduced [23]. While the glycerol $(B)$ and citric acid $(C)$ had significant effect on the resultant response because it had $p<0.05$ and $F>1$, where citric acid had a very strong effect on the response because it had probability value of $0.0006(p<0.05)$. Citric acid can form crosslinking with starch molecules, where the

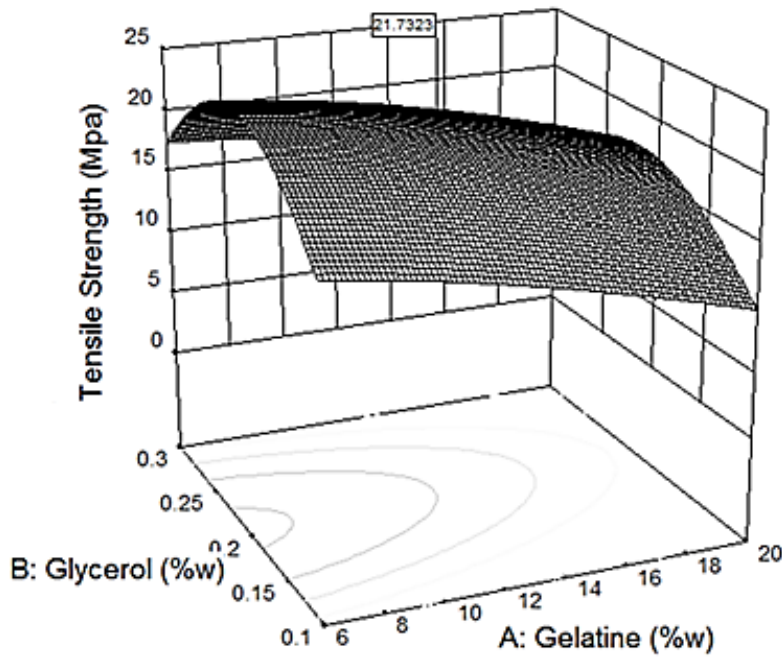

Fig 2. Three dimension model for optimization of tensile strength response molecular weight of the starch molecule will increase and provide better bonding between molecules, thereby increasing tensile strength. At low concentrations, citric acid is not strong enough to form crosslinking with molecules so that the resulting low in tensile strength. Conversely, if citric acid is added to an excessively high concentration it will cause excessive crosslinking and limit the mobility of starch molecules that cause the resulting tensile strength to be low [24].

Optimization of biofilm product was attained by using Design-Expert 8.0.6. The optimum condition was attained at the range of independent variables and maximum target of tensile strength and elongation at break. Optimization is used to determine the optimum conditions of the biofilms preparation variables such as gelatin, glycerol, and citric acid concentrations. The optimum conditions with optimum results can be seen in Table 6. Moreover, the contour model of three dimensions for optimum tensile strength and elongation at break can be seen in Fig. 2 and 3, respectively.<smiles>OCC(O)C(O)CO</smiles>

Glycerol

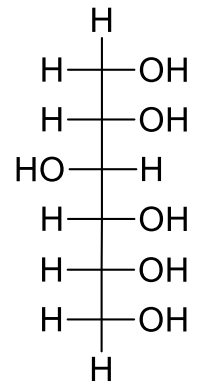

Sorbitol

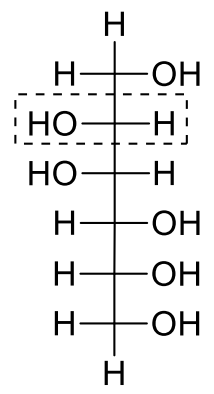

Manitol
Fig 1. Structure of glycerol, sorbitol and mannitol

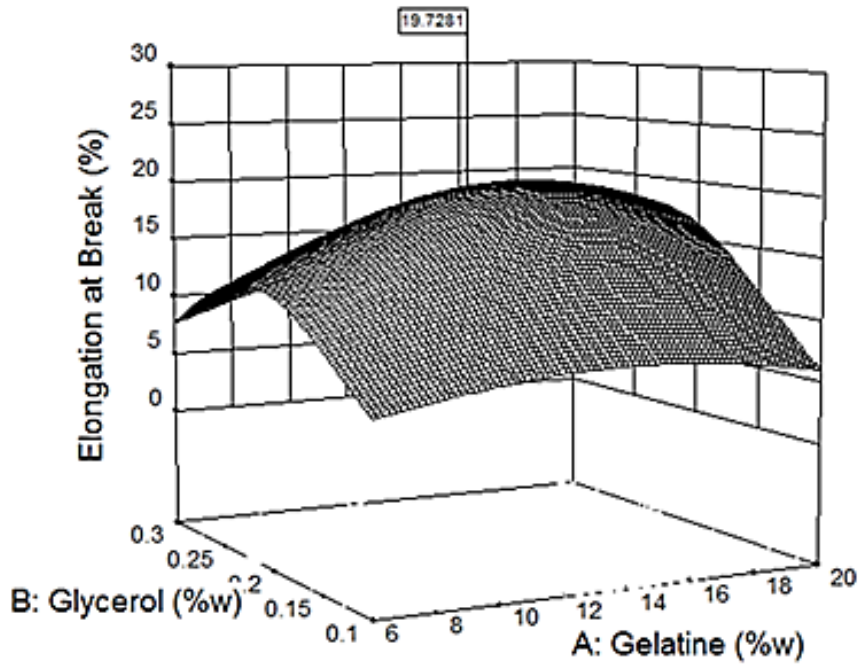

Fig 3. Three dimension model for optimization of elongation at break response 


\section{Durability Analysis}

Durability test is an analysis to find out how long the plastic can decompose in the soil or degradable bioplastic capability in soil characterized by shrinkage of mass (mass loss) in the soil at a certain time (45 days). In this research, the durability test had been introduced for samples of number 16 , number 2 , and blank sample with different content of gelatin. The result can be seen in Table 7. Gelatin accelerates the degradation process of the film because the gelatin is hydrolyzed by absorbing water in the soil so that the plastic polymer will break and break into smaller parts. The polymer will be degraded due to damage or deterioration due to the breaking of the chain link in the polymer [25]. In addition, the degradation process occurs due to microorganisms that play a role in soil breaking activity. Therefore, it can be said that gelatin can accelerate the process of degradation in the soil [25].

Citric acid as a crosslinker also affects the rate of degradation processes in the soil. In the soil, water diffuses into the film structure and causes swelling and increases degradation due to increased microbial growth. With the addition of citric acid, the process of water diffusion into the film will become obstructed which will then be followed by a decrease in the number of microorganisms present in the sample. Citric acid as a crosslinker causes the rate of degradation of the biofilm to be inhibited [26].

\section{Thermal Stability}

Thermogravimetry analysis (TGA) is a thermal analysis to assess the ability of decomposition of a material introduced by heating with increase of temperature. In this study, two samples were analyzed thermal stability, i.e. blank sample, and sample of number 16. In Fig. 4, decomposition of blank sample was occurred

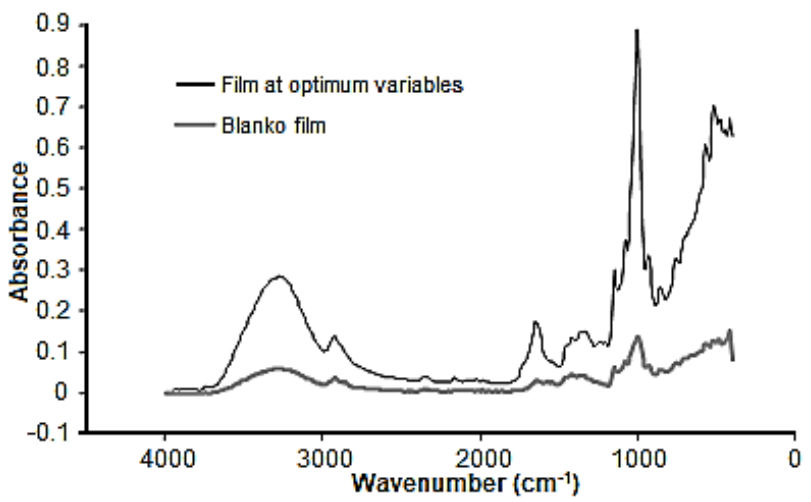

Fig 4. FTIR analysis of optimum biofilm product and blank sample in three stages, i.e. first stage of $97-10^{\circ} \mathrm{C}$, second stage of $280-320^{\circ} \mathrm{C}$, third stage of $440-520^{\circ} \mathrm{C}$. The first stage shows that the absorption of water absorbed in the material with evaporation of low molecular weight materials [27], the second stage shows the decomposition of organic materials added such as starch, gelatin, glycerol and citric acid $[19,27]$ while the third stage of the total decomposition of the material (inorganic residue) includes some gases contained in the material $\left(\mathrm{CO}_{2}, \mathrm{CO}, \mathrm{H}_{2} \mathrm{O}\right)$, volatile compounds and carbon compounds contained in the material [10]. While, in Fig. 4, decomposition of number 16 sample was occurred into 2 stages with the same range of heating, i.e. the first stage of $120-140{ }^{\circ} \mathrm{C}$, and the second stage of $240-300{ }^{\circ} \mathrm{C}$. The first stage was happened at higher temperatures because in this sample contained citric acid (as cross-linker) denoted as water evaporation and the light molecules. Therefore, decomposition of second sample of TGA analysis was more difficult than that of the blank [24]. It means, second sample needed more energy to crack the bonding of biofilm. Furthermore, the second sample did not achieve accomplishment of decomposition. It required high temperature than $600^{\circ} \mathrm{C}$ because a cross linking from citric acid forming bonding with other ingredients in the product. It can be concluded that the addition of gelatin, glycerol and citric acid tailored

Table 6. Point prediction at optimum condition

\begin{tabular}{|c|c|c|c|c|}
\hline $\begin{array}{c}\text { Gelatin } \\
\text { (wt.\%) }\end{array}$ & $\begin{array}{r}\text { Glycero } \\
\text { (wt.\%) }\end{array}$ & $\begin{array}{l}\text { Citric acid } \\
\text { (wt.\%) }\end{array}$ & $\begin{array}{l}\text { Tensile } \\
\text { Strength (MPa) }\end{array}$ & $\begin{array}{l}\text { Elongation } \\
\text { at break (\%) }\end{array}$ \\
\hline 12.98 & 0.22 & 0.27 & 21.73 & 19.73 \\
\hline
\end{tabular}

Table 7. Mass loss in durability test

\begin{tabular}{ccccc}
\hline No & $\begin{array}{c}\text { Gelatin } \\
\text { (wt.\%) }\end{array}$ & $\begin{array}{c}\text { Glycerol } \\
\text { (wt.\%) }\end{array}$ & $\begin{array}{c}\text { Citric acid } \\
\text { (wt.\%) }\end{array}$ & $\begin{array}{c}\text { Mass Loss } \\
(\%)\end{array}$ \\
\hline 1 & 13 & 0.2 & 0.19 & 35.12 \\
2 & 6 & 0.1 & 0.3 & 9.78 \\
3 & 0 & 0 & 0 & 8.91 \\
\hline
\end{tabular}

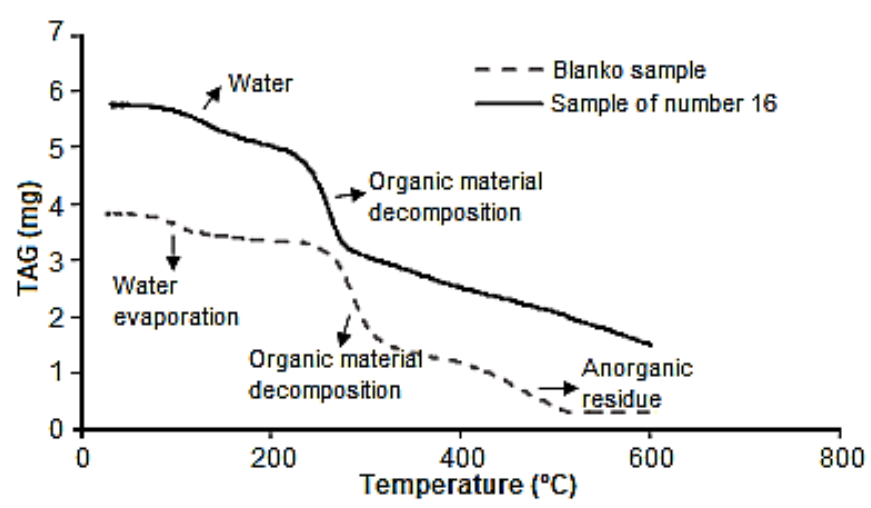

Fig 5. Thermo gravimetric analysis (TGA) of film 
the biofilm resisting against to thermal decomposition.

\section{Structure Analysis}

The result of FTIR analysis of the biofilm of blank and sample of number 16 can be seen in Fig. 5 . It can be seen several peaks visualized many bonding in the biofilm. In the range of $3000-3500 \mathrm{~cm}^{-1}$, this peak indicated the presence of hydroxyl bonding of starch. In the sample of number 16 , the wavenumber range of $3000-3500 \mathrm{~cm}^{-1}$ appeared higher peak than that of the biofilm product due to the fact that the hydroxyl bond in sample of number 16 was provided more sources from starch, gelatin, citric acid and glycerol. Another peak was at the wavenumber of $1700 \mathrm{~cm}^{-1}$. This wavenumber indicated the presence of $\mathrm{C}=\mathrm{O}$ bonds derived from citric acid added to the biofilm [24]. Other evidences at the wavenumber of $1575-1650 \mathrm{~cm}^{-1}$ showed the presence of amine $(\mathrm{NH})$ from added gelatin [28]. At the wavenumber range of $1575-1700 \mathrm{~cm}^{-1}$, the sample of number 16 was higher peak than that of the blank sample. Further observation, at $1550-1700 \mathrm{~cm}^{-1}$ of wavenumber there were two peaks, where one of these peaks disappeared in the sample of number 16. Peak at the wavenumber of $1638 \mathrm{~cm}^{-1}$ denotes the presence of water bond with the starch formed by hydrogen bonding [29], but in the sample of number 16, this peak was disappeared. It could be resulted from the addition of citric acid (low $\mathrm{pH}$ ) for the sample of number 16 by the ester formation involving the cluster of carboxylates and hydroxyl groups in polymer chains characterized by a peak at a wavenumber of 1700 $\mathrm{cm}^{-1}$ [1]. In the wavenumber range of $900-1000 \mathrm{~cm}^{-1}$, the peak indicated the presence of other compounds, i.e. $\left(\mathrm{CH}_{2}\right) \mathrm{n}$ was resulted the addition of glycerol as the source of the compound - $\left(\mathrm{CH}_{2}\right) n$ [29]. Based on FTIR analysis, it can be concluded that in the preparation of the biofilm, interaction can be occurred between molecules of several functional groups, such as $\mathrm{C}=\mathrm{O}$ bonds from citric acid, amine $(\mathrm{NH})$ from added gelatin, $-\left(\mathrm{CH}_{2}\right) \mathrm{n}$ from glycerol.

\section{CONCLUSION}

The optimum biofilm performance was composed by $12.98 \%$ gelatin, $0.22 \%$ glycerol and $0.27 \%$ citric acid with optimum tensile strength of $21.73 \mathrm{MPa}$ and elongation at break of $19.73 \%$. The greater of the gelatin content in the biofilm, the greater the tensile strength. The greater of the glycerol content in the film resulted the increase of elongation to break. Optimum citric acid content produced film with good tensile strength and elongation to break. Biofilms with a large gelatin content had experience with a rapid degradation process buried in the soil. Meanwhile, the increase of citric acid content in biofilm inhibited the rate of biofilm degradation in the soil. Biofilms with the addition of citric acid, glycerol and gelatin have better thermal stability compared to the biofilm blank sample. In preparation of the biofilm, there were interactions of the molecules with several ingredients. Biofilms with large citric acid content had the best water stability. Meanwhile, biofilms with too high gelatin content had poor water stability capability due to hydrophilicity of gelatin.

\section{REFERENCES}

[1] Alves, V.D., Ferreira, A.R., Costa, N., Freitas, F., Reis, M.A.M., and Coelhoso, I.M., 2011, Characterization of biodegradable films from the extracellular polysaccharide produced by Pseudomonas oleovorans grown on glycerol byproduct, Carbohydr. Polym., 83 (4), 1582-1590.

[2] Reddy, N., Chen, L., and Yang, Y., 2013, Biothermoplastics from hydrolyzed and citric acid crosslinked chicken feathers, Mater. Sci. Eng., C, 33 (3), 1203-1208.

[3] González, A., and Igarzabal, C.I.A., 2013, Soy protein - Poly (lactic acid) bilayer films as biodegradable material for active food packaging, Food Hydrocoll., 33 (2), 289-296.

[4] Ferreira, A.R.V, Torres, C.A.V, Freitas, F., Reis, M.A.M., Alves, V.D., and Coelhoso, I.M., 2014, Biodegradable films produced from the bacterial polysaccharide FucoPol, Int. J. Biol. Macromol., 71, 111-116.

[5] Cercel, F., Stroiu, M., Alexe, P., and laniţchi, D., 2015, Characterization of myofibrillar chicken breast proteins for obtain protein films and biodegradable coatings generation, Agric. Agric. Sci. Procedia, 6, 197-205.

[6] Salgado, P.R., Ortiz, S.E.M., Petruccelli, S., and Mauri, A.N., 2010, Biodegradable sunflower protein films naturally activated with antioxidant compounds, Food Hydrocolloids, 24 (5), 525-533.

[7] Souza, A.C., Benze, R., Ferrão, E.S., Ditchfield, C., Coelho, A.C.V., and Tadini, C.C., 2012, Cassava starch biodegradable films: Influence of glycerol and clay nanoparticles content on tensile and barrier properties and glass transition temperature, LWT Food Sci. Technol., 46 (1), 110-117.

[8] Tapia-Blácido, D., Sobral, P.J., and Menegalli, F.C., 2005, Development and characterization of biofilms based on amaranth flour (Amaranthus caudatus), J. Food Eng., 67 (1-2), 215-223.

[9] Sousa, G.M., Jünior, M.S.S., and Yamashita, F., 2013, Active biodegradable films produced with blends of rice flour and poly(butylene adipate coterephthalate): Effect of potassium sorbate on film characteristics, Mater. Sci. Eng., C, 33 (6), 31533159. 
[10] Mendes, J.F., Paschoalin, R.T., Carmona, V.B., Neto, A.R.S., Marques, A.C.P., Marconcini, J.M., Mattoso, L.H.C., Medeiros, E.S., and Oliveira, J.E., 2016, Biodegradable polymer blends based on corn starch and thermoplastic chitosan processed by extrusion, Carbohydr. Polym., 137, 452-458.

[11] Taufik and Fatma, 2009, "Karakterisasi Edible Film Berbahan Dasar Gelatin Kulit Kaki Broiler" in Seminar Nasional Peternakan, Universitas Hasanudin, Makasar, 220-228.

[12] Hasdar, M., Erwanto, Y., and Triatmojo, S., 2011, Karakteristik edible film yang diproduksi dari kombinasi gelatin kulit kaki ayam dan soy protein isolate, Buletin Peternakan, 35 (3), 188-196.

[13] Hidayati, K., and Nugraha I., 2014, Sintesis dan karakteristisasi komposit edible film berbahan dasar gelatin ceker ayam dan montmorillonit, Seminar Nasional Kimia dan Pendidikan Kimia VI, PMIPA FKIP UNS.

[14] Yun, H., Kim, M.K., Kwak, H.W., Lee, J.Y., Kim, M.H., and Lee, K.H., 2016, The role of glycerol and water in flexible silk sericin film, Int. J. Biol. Macromol., 82, 945-951.

[15] Okoye, P.U., and Hameed, B.H., 2016, Review on recent progress in catalytic carboxylation and acetylation of glycerol as a byproduct of biodiesel production, Renewable Sustainable Energy Rev., 53, 558-574.

[16] Olsson, E., Hedenqvist, M.S., Johansson, C., and Järnström, L., 2013, Influence of citric acid and curing on moisture sorption, diffusion and permeability of starch films, Carbohydr. Polym., 94 (2), 765-772.

[17] Mekonnen, T., Mussone, P., Khalil, H., and Bressler, D., 2013, Progress in bio-based plastics and plasticizing modifications, J. Mater. Chem. A, 1, 13379-13398.

[18] Rammaya, K., Ying, V.Q., and Babji, A.S., Physicochemical analysis of gelatin extracted from mechanically deboned chicken meat (MDCM) residue, 5 (1), Int. J. Food Nutr. Public Health, 147168.

[19] Lee, J.H., Lee, J., and Song, K.B., 2015, Development of a chicken feet protein film containing essential oils, Food Hydrocolloids, 46, 208-215.
[20] Firdaus, F., 2004, Potensi limbah padat-cair industri tepung tapioka sebagai bahan baku film plastik biodegradabel, Jurnal Logika, 1 (2), 38-44.

[21] Penjumras, P., Rahman, R.A., Talib, R.A., and Abdan, K., 2015, Response surface methodology for the optimization of preparation of biocomposites based on poly(lactic acid) and durian peel cellulose, Sci. World J., 2015, 293609.

[22] Hivechi, A., Bahrami, S.H., Arami, M., and Karimi, A., 2015, Ultrasonic mediated production of carboxymethyl cellulose: Optimization of conditions using response surface methodology, Carbohydr. Polym., 134, 278-284.

[23] Cao, N., Yang, X., and Fu, Y., 2009, Effects of various plasticizers on mechanical and water vapor barrier properties of gelatin films, Food Hydrocolloids, 23 (3), 729-735.

[24] Reddy, N., and Yang, Y., 2010, Citric acid crosslinking of starch films, Food Chem., 118 (3), 702711.

[25] Akbar, F., Anita, Z., and Harahap, H., 2013, Pengaruh waktu simpan film plastik biodegradasi dari pati kulit singkong terhadap sifat mekanikalnya, Jurnal Teknik Kimia USU, 2 (2), 37-41.

[26] Seligra, P.G., Jaramillo, C.M., Famá, L., and Goyanes, S., 2016, Biodegradable and nonretrogradable eco-films based on starch-glycerol with citric acid as crosslinking agent, Carbohydr. Polym., 138, 66-74.

[27] Cyras, V.P., Manfredi, L.B., Ton-That, M.T., and Vázquez, A., 2008, Physical and mechanical properties of thermoplastic starch/montmorillonite nanocomposite films, 73, 55-63.

[28] Alcázar-Alay, S.C., and Meireles, M.A.A., 2015, Physicochemical properties, modifications and applications of starches from different botanical sources, Food Sci. Technol., 35 (2), 215-236.

[29] Aydin, A.A., and Ilberg, V., 2016, Effect of different polyol-based plasticizers on thermal properties of polyvinyl alcohol:starch blends, Carbohydr. Polym., 136, 441-448. 